\title{
Preparation of High Dietary Fibre Cookies from Pineapple (Ananas comosus) Pomace
}

\author{
Lourembam Kamala Devi, Sachin Karoulia, Neha Chaudhary \\ Corresponding Author \\ Lourembam Kamala Devi, Sachin Karoulia
}

Baba farid Institute of Science and Research, Dehradun, U.K.

\begin{abstract}
The wheat flour, pine-apple pomace, egg, butter, sugar, and essence were used for preparation of cookies. The pine -apple pomace is rich in high dietary fibre, it is also contains calcium, phosphorus and iron. The egg was used as the binding agents. The pine apple essence was added in order to enhance the flavour of the product. Sodium benzoate was used in small quality for preservative in the cookies. The product was bake and was served to different panel members for sensory evaluation on the basis of 9-point hedonic scale. The product was tested for proximate analysis in order to check the physico-chemical properties by AOAC and Ranganna method.
\end{abstract}

Keywords: pineapple pomace, wheat flour, cookies, sensory evaluation, standardization

\section{Introduction}

Cookies have now become loved fast food product for every age group. These are easy to carry, tasty to eat, cholesterol free and reasonable at cost. In India about 25 percent of the wheat is used in preparation of baked goods. (Kamaljit et al., 2010). Cookies are one of the best known quick snake products. They are characterized by a formula high in sugar and shortenings and low in water. The main ingredients of cookies are wheat flour, fat and sugar. The chemical composition of cookies is of significant importance as they contain 22-30 percent of fat, 4-8 percent protein content and 60-70 percent carbohydrate. (Farheena Iftikhar et al., 2015).

Pineapple (Ananas comosus), fruit is good source of carotene (vitamin A) and ascorbic acid (vitamin C) and is fairly rich in vitamin $\mathrm{B}$ and B12, it is also contain carbohydrate, protein, fat, fibre, calcium and iron. Pineapple world production reached 21.8 million of tons in 2011 (FAO, 2013)). Consequently, it is of vital importance to reuse industrial by products in order to improve the process economics and its sustainability. It is well-known that dietary fibre plays an important role in human health, promoting several physiological and metabolic positive effects (Raninen et al., 2011). According to FDA (2013), to have a product with a "high source of fibre" and "good source of fibre" claim, it must contain, respectively, 20 percent or more fibre and 10-19 percent of fibre of the recommended daily value for dietary fibre in a serving size. About 76 percent of pineapple by product (peel and heart) is fibre, from which 99.2 percent is the insoluble fraction and 0.8 percent is the soluble fraction. This pineapple pomace rich in dietary fibre it also contain calcium, phosphorus and iron. They could be used as a potential food ingredient to improve nutritional quality of foods.

Wheat (Triticum aestivum) is grown throughout the world. Wheat is nutritious, easy to store and transport and can be processed into various types of food. Wheat is considered a good source of protein, minerals, B-group vitamins and dietary fibre. Wheat germ has only one half the glutamine and proline of flour, but the levels of alanine, arginine, asparagines, glysine, lysine and threonine are double (Cornell, 2003). Wheat flour is used to prepare bread, produce biscuits, confectionary products, noodles and vital wheat gluten or seitan. Wheat germ and wheat bran can be a good source of dietary fibre helping in the prevention and treatment of some digestive disorders.

\section{Materials and Methods}

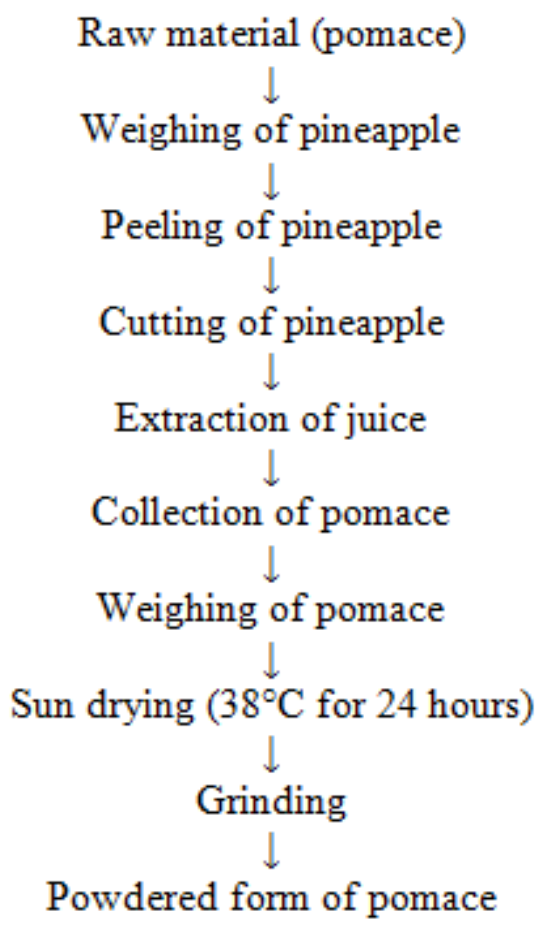




\section{International Journal of Science and Research (IJSR) \\ ISSN (Online): 2319-7064}

Index Copernicus Value (2013): 6.14 | Impact Factor (2015): 6.391

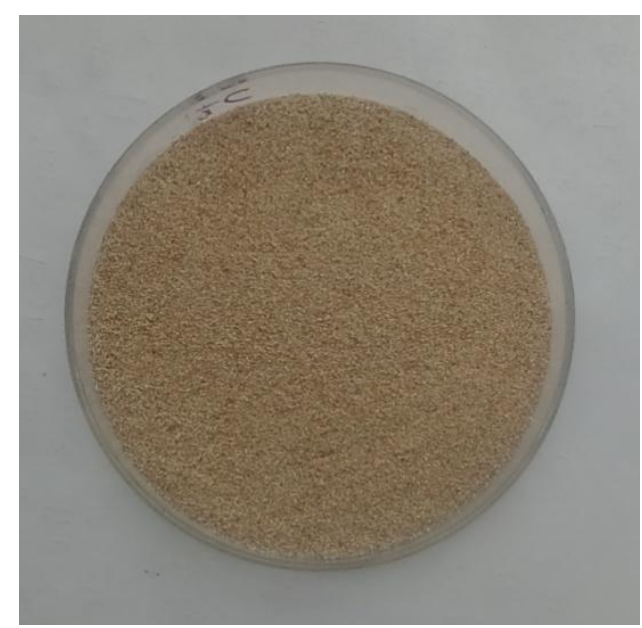

Figure 1: Flow chart showing preparation of Pineapple pomace

Raw material

(Wheat flour, pineapple pomace, egg, butter, sugar) $\downarrow$ Sieving of flour $\downarrow$ Weighing of raw material
$\downarrow$
Preheating of Oven $\left(200^{\circ} \mathrm{C}\right.$ for 20 minutes)
$\downarrow$
Witting of butter $(23 \mathrm{gm})$ for 10 minutes $\downarrow$ Addition of sugar (22gm) $\downarrow$ Mixing (10 minutes)

$\downarrow$

Addition of egg yolk and egg white (12ml) Mixing ( 5 minutes) $\downarrow$

Addition of wheat flour and baking powder (43:1) Mixing (5 minutes)

$$
\downarrow
$$

Addition of pineapple pomace ( $3 \mathrm{gm}$ ) and mix gently

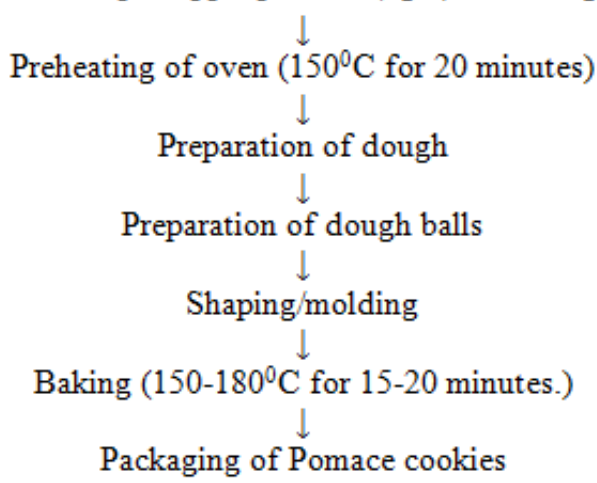

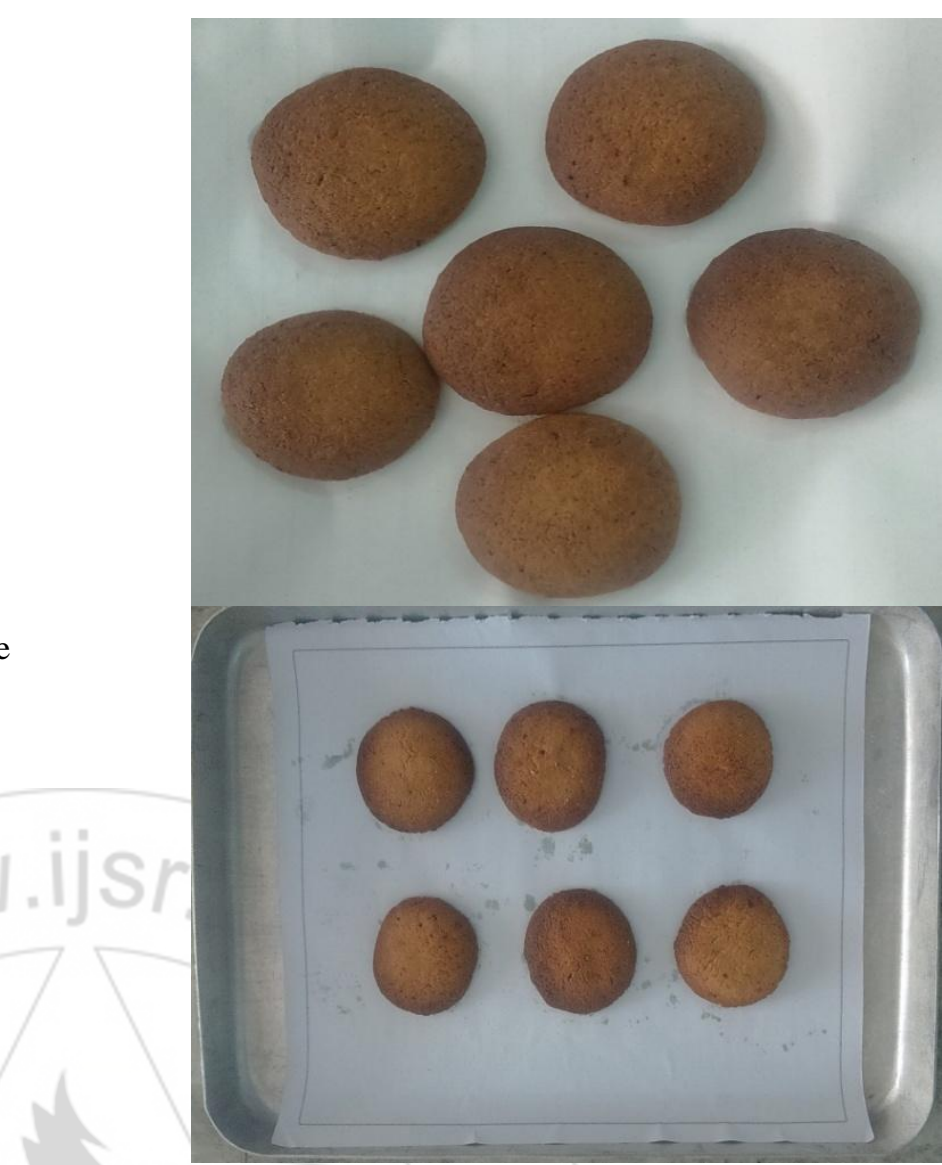

Figure 2: Flow chart showing preparation of cookies

\section{Preparation of Cookies}

Wheat flour, pineapple, eggs, butter and sugar were procured from the local market of Dehradun. All the raw material was properly measured according to the ratio required in cookies. The juice was extracted from the fully-ripened pineapple. The by-product obtained was sun dried for 24 hours to obtain pineapple pomace. The wheat flour was sieved through fine sieves to avoid the dirt and unwanted particles. Then the butter $(23 \mathrm{~g})$ was creamed for 10 minutes to obtain a creamy and even texture of butter. Sugar $(22 \mathrm{~g})$ was added to the butter and mixed gently until the sugar was dissolved and a foamy consistency was obtained. The egg was beaten and measured (12ml.) then added in the batter, whereas, on the other side, the oven was preheated at $150^{\circ} \mathrm{C}$ for 20 minutes. The weighed wheat flour and baking powder $(43: 1)$ were mixed and sieved together and were added to the batter. 2 drops of pineapple essence were also added in the batter and mixed properly. In the end, pineapple pomace was weighed $(3 \mathrm{~g})$ and added to the dough. The small balls were prepared out of dough and were pressed into the shape of cookies, further the round shaped cookies were kept on the baking tray and placed in preheated oven at $150-180^{\circ} \mathrm{C}$ for $15-20$ minutes. 


\section{International Journal of Science and Research (IJSR)}

ISSN (Online): 2319-7064

Index Copernicus Value (2013): 6.14 | Impact Factor (2015): 6.391

\section{Result and Discussion}

Chemical composition of pine- apple pomace:

Table 1: Composition of pine- pomace in (100g)

\begin{tabular}{|c|c|c|c|c|c|c|c|c|}
\hline $\begin{array}{c}\text { Name of } \\
\text { pomace }\end{array}$ & $\begin{array}{c}\text { Food } \\
\text { energy }\end{array}$ & $\begin{array}{c}\text { Moisture } \\
\text { percent }\end{array}$ & $\begin{array}{c}\text { Protein } \\
\text { percent }\end{array}$ & $\begin{array}{c}\text { Fat } \\
\text { percent }\end{array}$ & $\begin{array}{c}\text { Total } \\
\text { Carbohydrate } \\
(\mathbf{g m})\end{array}$ & $\begin{array}{c}\text { Calcium } \\
(\mathbf{m g})\end{array}$ & $\begin{array}{c}\text { Iron } \\
(\mathbf{m g})\end{array}$ & $\begin{array}{c}\text { Phosphorus } \\
(\mathbf{m g})\end{array}$ \\
\hline Pineapple & 15.6 & 3.77 & 4.71 & 0.61 & 43.46 & 10 & 5 & 4 \\
\hline
\end{tabular}

Chemical composition of raw wheat flour:

Table 2: Composition of wheat flour (percent baking matter basis)

\begin{tabular}{|c|c|}
\hline PARAMETERS & 14 \\
\hline Moisture (percent) & $1.2-1.7$ \\
\hline Ash (percent) & 1.2 \\
\hline Fat (percent) & $9-14$ \\
\hline Protein (percent) & $1.7-2.6$ \\
\hline Fibre (percent) & $54-62$ \\
\hline Carbohydrate (percent) &
\end{tabular}

Chemical composition of pine-apple pomace cookies:

Table 3: Proximate analysis of pine-apple pomace cookies

\begin{tabular}{|c|c|}
\hline PARAMETERS & Pineapple pomace cookies \\
\hline Moisture (percent) & 3.23 \\
\hline Ash (percent) & 2.0 \\
\hline Fat (percent) & 3.06 \\
\hline Protein (percent) & 0.09 \\
\hline Fibre (percent) & 81.32 \\
\hline
\end{tabular}

Moisture content: The moisture content of pine-apple pomace cookies was 3.23 percent (Table 3).

Ash content: The pine-apple pomace cookies contained 2.0 percent Ash content (Table 3).

Fat content: The fat content of pine-apple pomace cookies in percentage of 3.5 (Table 3 ).

Protein content: The protein content in pine-apple pomace cookies was 4.10 percent (Table3).

Fibre content: The pine-apple pomace cookies contained fibre in percentage of 17.10 (Table3)

Physico-chemical properties of pine-apple pomace cookies:

The physico-chemical properties of the pine-apple pomace cookies are given in table 4 . The diameter of pine-apple pomace was $2.5 \mathrm{~cm}$ and the weight of the cookies was $6 \mathrm{~g}$. Regarding creaming time for pine-apple pomace cookies, the time was 5-10 minutes. The bake of pine-apple pomace cookies diameter was changed individually depending upon the puff occurred in pine-apple pomace cookies. The diameter of bake pine- apple pomace cookies was about 5 $\mathrm{cm}$ and weight was $12 \mathrm{~g}$.

Table 4: Physico-chemical properties of the pine-apple pomace cookies

\begin{tabular}{|c|c|}
\hline Criteria & \\
\hline Diameter of wet cookies $(\mathbf{g})$ & 5 \\
\hline Weight of wet cookies $(\mathbf{g})$ & 14 \\
\hline Creaming time of cookies $(\mathbf{m i n}$ ) & $5-10$ \\
\hline Baking time $(\mathbf{m i n})$ & $20-30$ \\
\hline Diameter of baked cookies(cm) & 5 \\
\hline Weight of baked cookies $(\mathbf{g m})$ & 12 \\
\hline
\end{tabular}

Sensory evaluation score of prepared pine -apple pomace cookies:

The mean acceptability score obtained by sensory evaluation of pine-apple pomace cookies are in table 3 . The overall acceptability of pine-apple pomace cookies was 7.75, which was more than acceptability level 5. The acceptability parameter was judged by 10 sensory panelist member followed by 9 -point hedonic scale.

The texture attribute was found to be maximum for the pine-apple pomace cookies with a score of 7.5, which was judged by 10 sensory panelists according to 9-point hedonic scale.

The taste attribute was found to be maximum for the pineapple pomace cookies with a score of 7 , which was judged by panelists followed by 9 -point hedonic scale.

The color attributes got maximum marks for the pine-apple pomace cookies with a score of 7.6, which was judged by 10 judges followed by 9 -point hedonic scale. 


\section{International Journal of Science and Research (IJSR) \\ ISSN (Online): 2319-7064}

Index Copernicus Value (2013): 6.14 | Impact Factor (2015): 6.391

Sensory Evaluation: - 9 point hedonic scale

Table 5: Sensory evaluation of score card of pine-apple pomace cookies

\begin{tabular}{|c|c|c|c|c|c|c|c|c|c|c|c|}
\hline Parameter & Panelist1 & Panelist2 & Panelist3 & Panelist4 & Panelist5 & Panelist6 & Panelist7 & Panelist8 & Panelist9 & $\begin{array}{c}\text { Panelist } \\
10\end{array}$ & OAA \\
\hline Color & 8 & 7 & $\mathbf{7}$ & 7 & 7 & 6 & 7 & 7 & 7 & 7 & 7 \\
\hline Texture & $\mathbf{7}$ & 8 & 8 & 8 & 8 & 6 & 8 & 8 & 7 & 7 & 7.5 \\
\hline Flavour & $\mathbf{7}$ & 7 & 8 & 6 & 6 & 7 & 7.5 & 7.5 & 5 & 7 & 6.8 \\
\hline Taste & 6 & 8 & 8 & 8 & 7 & 6 & 7 & 7 & 6 & 7 & 7 \\
\hline $\begin{array}{c}\text { Overall } \\
\text { acceptability }\end{array}$ & 7.25 & 7.5 & 7.75 & 7.25 & 7 & 6.25 & 7.37 & 7.37 & 6.25 & 7 & 7.149 \\
\hline
\end{tabular}

\section{Storage studies of pine-apple pomace cookies:}

The storages and shelf-life studies of pine-apple cookies was for the period of 1 month in the air-tight package at room temperature.
There was no remarkable change observed in the content of moisture, texture and flavour till 1 month of storage. The pine-apple pomace cookies sample was shelf -stable up to 3 months of storage at ambient conditions. The effect of storage time on physico-chemical properties of pineapple cookies is shown in Table 6.

Table 6: The effect of storage time on physico-chemical properties of pine-apple cookies

\begin{tabular}{|c|c|c|c|c|c|c|c|}
\hline Period of storage & 0 & 5 & 10 & 15 & 20 & 25 & 30 \\
\hline Cookies & cookies & Cookies & cookies & cookies & cookies & cookies & cookies \\
\hline Moisture \% & 3.23 & 3.20 & 3.10 & 3.10 & 3.06 & 3.01 & 2.98 \\
\hline Observation texture & Crisp & Crisp & Crisp & Crisp & Crisp & Crisp & Crisp \\
\hline Flavour & Good & Good & Good & Good & Good & Good & Good \\
\hline Remarks & Good & Good & Good & Good & Good & Good & Good \\
\hline
\end{tabular}

\section{Storage studies of pine-apple pomace cookies} Microbial study of pine-apple pomace cookies-

The microbial study of pine-apple pomace cookies was done by two process- total plate count method and yeast \& mold count method.
Potato dextrose agar media was used for total plate count method. At the initial time, the microbial growth was nil. Total plate count was not observed up to 2 months storage. In the completion of 3 months storage the microbial growth was $1.0 \times 10^{1}, 1.0 \times 10^{1} \mathrm{cfu} / \mathrm{g}$, respectively and at the initial stage, the yeast and mold growth was nil. (Table: 7 )

Table 7: Microbial count in pine-apple cookies during storage

\begin{tabular}{|c|c|c|c|c|}
\hline & \multicolumn{2}{|c|}{ Total plate count } & \multicolumn{2}{c|}{ Yeast \& Mold count } \\
\hline \multirow{2}{*}{ Treatment } & cookies (control) & $\begin{array}{c}\text { Pine-apple pomace } \\
\text { cookies }\end{array}$ & $\begin{array}{c}\text { Pine-apple pomace } \\
\text { cookies }\end{array}$ & 0 \\
\hline 0 days & 0 & 0 & 0 & 0 \\
\hline 15 days & 0 & 0 & 0 & 0 \\
\hline 30 days & 0 & 0 & $1.0 \times 10^{1}$ & $1.0 \times 10^{1}$ \\
\hline 45 days & 0 & 0 & $1.0 \times 10^{1}$ & $1.0 \times 10^{1}$ \\
\hline 6 days & 0 & 0 & control) & 0 \\
\hline
\end{tabular}

\section{Reference}

[1] Alan JB, Changrun LMS, Fergus M, Clydesdale FACN, Decker EA, 2000. Potential of wheat-based breakfast cereals as a source of dietary antioxidants. Journal of the American College of Nutrition, 19(3): 308S-311S.

[2] Kamaljit K, Baljit S, Amarjeet K (2010). Preparation of bakery products by incorporating cowpea flour as a functional ingredient. American journal of food technology, 5(2): 130-135

[3] Farheena Iftikar, Avneesh Kumar, Ugma Altaf (2015). Development and Quality Evaluation of Cookies Fortified with date paste (Phoenix dactylifera L.). International journal of science, 3: 975-978.

[4] P Kumar, RK Yadava, B Gollen, S Kumar, RK Verma, S Yadav (2011). Nutritional Contents and Medicinal Properties of Wheat: A Review. Life Science and medicine Research. Vol. 2011: 1-10
[5] Miriam Mabel Selani, Solange Guidolin Canniatti Brazaca, Carlos Tadeu dos Santos Dias, Wajira S. Ratnayake, Rolando A. Flores, Andreia Bianchini (2014): Characterisation and potential application of pineapple pomace in an extruded product for fibre enhancement. Elsevier. 163: 23-30.

[6] FAO (Food and Agriculture Organization of the United Nations). FAOSTAT Statistics Database Agriculture, 2013. URL <http://faostat.fao.org/>. Accessed 10.05.13

[7] FDA (Food and Drug Administration). Code of Federal Regulations. Title 21 - Food and Drugs- Food Labeling, Part 101 - Food Labeling, Subpart D Specific Requirements for Nutrient Content Claims, 2013,

URL:<http://www.accessdata.fda.gov/scripts/cdrh/cfd ocs/cfcfr/CFRSearch.cfm?fr=101.54, Accessed 


\section{International Journal of Science and Research (IJSR) \\ ISSN (Online): 2319-7064}

Index Copernicus Value (2013): 6.14 | Impact Factor (2015): 6.391

[8] Raninen, K., Lappi, J., Mykkanen, H., \& Poutanen, K. (2011). Dietary fibre type reflects Physiological functionality: comparison of grain fibre, inulin and polydextrose. Nutrition Reviews, 69, 9-21.

[9] Martinez, R., Torres, P., Meneses, M. A., Figueroa, J. G., Perez-Alvarez, J. A., \& Viuda-Martos, M. (2012). Chemical, technological and in vitro antioxidant properties of mango, guava, pine-apple and passion fruit dietary fibre concentrate. Food Chemistry, 135, 1520-1526.

[10] Kuldip D Ade, Er. Aditya Lal, Akash S Rathod (2014). Development and Quality Evaluation of Pineapple Pomace and Wheat Bran Fortified Biscuits. International Journal of Research in Engineering \& Advanced Technology, 2: 2320-879).

[11] Cornell H (2003) In: Cauvain SP (ed) Bread Making: Improving Quality. Woodhead Publishing, Cambridge

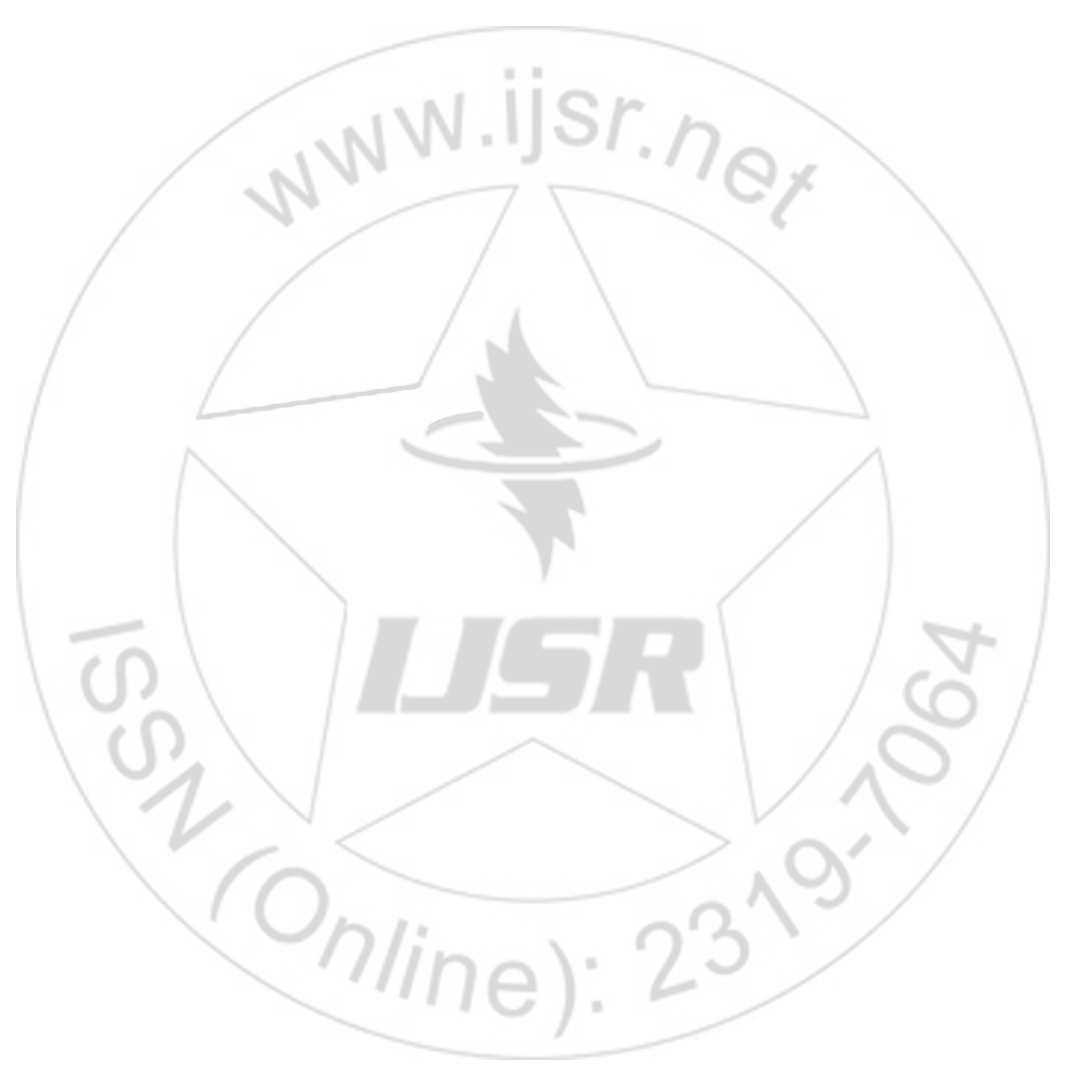

Volume 5 Issue 5, May 2016 